\title{
Are we there yet? Immersive Virtual Reality to improve cognitive function in Dementia and Mild Cognitive Impairment
}

Article Type: Review

Acknowledgements: No funding was received for this research

Author Contributions: MS and RT were responsible for screening of papers, MS, $R T, C C$, and $K W$ were responsible for final selection of papers. MS, RT, CC and KW were responsible for drafting and final production of the research paper

Conflicts of Interest: The Authors did not receive any funding for this research and have no competing interests

Keywords: Virtual Reality, Dementia, Mild cognitive impairment, Cognition 


\section{Abstract}

Cognitive training therapies may delay cognitive deterioration in dementia. There is potential to enhance delivery through immersive virtual reality (IVR), as removing potential distractors for cognitively impaired individuals can enhance their experience, resulting in increased engagement. Evidence in this field is emerging and not yet synthesised. We aimed to summarise research investigating the use of IVR in dementia to evaluate the current extent of use, acceptability, feasibility and potential effectiveness. We also aimed to identify gaps in current research, and create a set of recommendations in utilising this therapy. A systematic literature review was conducted. Our review was registered with PROSPERO, registration number: CRD42019122295. We undertook searches of 5 databases, article references and citations. Key authors in the field of healthcare VR were also contacted to identify additional papers. Articles were assessed for inclusion by two researchers independently. Data was extracted using standardised forms. Our search identified a total of 2824 citations, following screening for duplicates and application of inclusion and exclusion criteria, 5 studies were included for analysis. Included studies were heterogeneous, with small sample sizes and mixed outcomes. We were unable to reach definitive conclusions over the use, acceptability and effectiveness of IVR for dementia and $\mathrm{MCl}$. Future studies should focus on ensuring their interventions are truly immersive, developing more robust controls and account for the rapid rate of obsolescence in digital technologies. 


\section{Introduction}

\subsection{Rationale}

Dementia has a far reaching impact on individuals, their families and society. In the United Kingdom alone, the annual estimated costs of dementia care, including health, social and unpaid care, are over £25 billion every year (Alzheimer’s Society, 2014). This does not account for the wider societal and productivity losses associated with dementia, which could increase this number by a factor of two (Wimo, Winblad, \& Jonsson, 2010). As the population ages and increases in size globally, increasing numbers of people will suffer from dementia unless effective health interventions are put in place (Prince et al., 2016). Simultaneously, increasing numbers of people are affected by mild cognitive impairment (MCl), a possible precursor to dementia and although distinct from dementia, individuals with $\mathrm{MCl}$ are much more likely to go on to develop dementia (Knopman \& Petersen, 2014).

Dementia can be defined as a syndrome with a noticeable decline in at least two of the five cognitive domains; memory, executive functioning, attention, visuospatial skills and language (Hugo \& Ganguli, 2014). As dementia progresses, individuals experience a broad range of difficulties, from loss of attention, loss of memory, to depression and eventually declining insofar to be unable to perform daily activities independently (Silveri, Reali, Jenner, \& Puopolo, 2007). Many causes of dementia have few pharmacological therapies, whilst the available medications offer limited benefits and often focus on sedation, furthering a loss of autonomy (Schwarz, Froelich, \& Burns, 2012). 
As a result, there is now more emphasis on non-pharmacological therapies aiming to delay the decline of cognitive function in dementia and $\mathrm{MCl}$ (York Health Economics Consortium, 2017). These therapies range from music therapy targeting language, to animal-assisted therapies aiming to improve attention (Bannan \& MontgomerySmith, 2008; Dashnaw Stiles, 2001). However, cognitive therapies and rehabilitation for the management of dementia appear to show mixed results (Carrion, Folkvord, Anastasiadou, \& Aymerich, 2018).

However, as the volume of people with dementia and cognitive impairment increases and funding for healthcare becomes scarcer, it will become increasingly difficult to deliver face-to-face therapies; meaning there is a need for cost-effective, wide-scale solutions to be developed (Barr, Bambra, \& Whitehead, 2014). The use of mobile health applications to deliver therapies has exploded over the last decade, with demonstrable benefits from for example quitting smoking to physical therapies (Ernsting et al., 2017; Lin et al., 2018). For dementia, however, the delivery of mobile health applications presents an added challenge in the loss of attention, making it difficult to engage with these interventions (Forstmeier \& Maercker, 2015).

Therapies and training delivered through immersive Virtual Reality (IVR) have been suggested to enhance attention and reduce distraction in those with other conditions such as in attention deficit hyperactivity disorder and traumatic brain injuries attention difficulties (Bashiri, Ghazisaeedi, \& Shahmoradi, 2017; Olk, Dinu, Zielinski, \& Kopper, 2018). This shows particular promise in dementia and $\mathrm{MCl}$, with the ability to provide a more personalised feedback experience and create a more 
stimulating and familiar environment that has the potential to engage persons with the dementia in a unique way (Cohen-Mansfield, Thein, Dakheel-Ali, \& Marx, 2010; Leone et al., 2012; Rizzo \& Kim, 2005).

Although 'virtual reality' has been trialled as a medium to deliver therapies in healthcare for over twenty years, the use of true virtual reality, one where an individual is immersed in a virtual world they are able to interact with, is only a recent development (Huygelier, Schraepen, van Ee, Vanden Abeele, \& Gillebert, 2019; Riva, 2002). IVR has been defined as an immersive experience delivered through a combination of technologies, including a head-mounted display (HMD), headphones with sound/music and noise reduction, a rumble pad, joystick or another device for manipulation/navigation of the virtual environment (VE) (Huygelier et al., 2019; Li, Montano, Chen, \& Gold, 2011). As a relatively recent development, healthcare uses of IVR are only just beginning. As hardware and software capabilities improve, these technologies now have the ability to provide complex and user friendly therapies.

However, the use of IVR in older people is not well understood, with issues ranging from VR sickness to the more abstract potential of new technology rejection, additionally there is a wide range in variability in the level of immersion achieved (Benoit et al., 2015; Huygelier et al., 2019; Kim, Park, Choi, \& Choe, 2018). As a result, we conducted a systematic review of current IVR interventions for dementia and $\mathrm{MCl}$, to determine the current extent of their use, acceptability, feasibility and potential effectiveness. 


\subsection{Objectives}

\section{Primary Objectives}

1. Summarise the current research investigating the use, acceptability and feasibility of IVR interventions for cognition in dementia and $\mathrm{MCI}$

2. Synthesise the evidence for potential effectiveness of IVR as a strategy for cognitive training in dementia and $\mathrm{MCl}$

3. Highlight the limitations in current literature and develop a set of recommendations for future IVR research in cognitive training for dementia and $\mathrm{MCl}$ 


\section{Method}

\subsection{Protocol and Registration}

This systematic review of published literature was conducted according to PRISMA guidelines and the format of this report follows the PRISMA statement (Moher, Liberati, Tetzlaff, \& Altman, 2009). Our review was registered with PROSPERO, registration number: CRD42019122295 (Chien, Khan, \& Siassakos, 2012).

\subsection{Inclusion and Exclusion criteria}

Studies were eligible for inclusion if they were primary research studies conducted on humans and focused on IVR studies which evaluated IVR as an intervention for people with dementia or $\mathrm{MCI}$. All study types were included, such as feasibility studies, pilot studies and efficacy/effectiveness studies. Studies were excluded if the article was a conference abstract/proceeding (efforts were made to identify if a full paper version of the abstract identified had been published). Studies were excluded if they targeted physical rehabilitation only in patient groups that had Parkinson's disease (without documented cognitive impairment), and without analysing outcomes of patients separated by their cognitive function. Studies were excluded if they solely looked at the general population of older people or those with subjective cognitive impairment, and did not report findings specifically for those with dementia or MCI. Published research was accessed if it was available between 01/01/2000 and $06 / 12 / 2018$. Studies published before this date would not have had sufficient technology to produce an IVR experience (Cipresso, Giglioli, Raya, \& Riva, 2018). 


\subsection{Search Strategy}

Search terms were developed and based on other clinical IVR-based systematic reviews (Cano Porras, Siemonsma, Inzelberg, Zeilig, \& Plotnik, 2018; Dockx et al., 2016). Search terms are described in Table 1, the strategy was developed utilising the PICOS model (Methley, Campbell, Chew-Graham, McNally, \& Cheraghi-Sohi, 2014). Five databases were searched: CINAHL, PsycINFO, PubMed/Medline, EMBase, OVID Medline. Further material was sought by contacting the authors of initially included papers, hand-searching of key journals in the fields of IVR and Dementia/MCl, and article reference lists. Key authors were also contacted to ask if they had published any further article, forward citation tracking was also conducted to identify further articles of relevance that had cited our identified articles.

Table 1: Summary of search terms, utilising PICOS model (Methley et al., 2014)

\subsection{Study Selection}

One author (M.S.) performed initial eligibility assessment by first checking the title and abstract to ensure only papers investigating virtual reality in dementia or $\mathrm{MCl}$ were included. Two authors (M.S. and R.T.) then assessed the full text of remaining articles to reach a consensus on articles for inclusion, based on the preselecting inclusion and exclusion criteria. Disagreements on included papers were discussed and resolved with K.W. and C.C. 


\subsection{Data Extraction and risk of bias assessment}

Data from included papers was manually extracted onto data collection tables. We collected data on participants (medical condition, sample size, age, time of diagnosis), type of intervention (method of IVR delivery, length of IVR intervention, number of sessions, setting of IVR delivery), reported outcomes, effectiveness of IVR, recruitment rates and attrition rates. Additionally, we extracted data on characteristics of the study (design, country and setting). The included articles were assessed for bias using the Critical Skills Appraisal Programme (CASP) checklist for randomised control trials, however due to the relatively new nature of the field, no studies were excluded based on their risk of bias. We also included an additional systemic bias assessment as part of the data extraction portion of study analyses.

\subsection{Defining and Assessing Extent of Immersion}

Immersion can be defined as the extent to which a user feels 'present' in their virtual environment (Slater \& Wilbur, 1997). Immersion is difficult to quantify and is largely judged by the quality of the hardware and the software used in the intervention, for example the use of higher definition displays may be considered to offer a more significant level of immersion (Bowman \& McMahan, 2007; Rash, 2008; Slater \& Wilbur, 1997). Presence, however, refers to the participant's sense of being within an environment created using technology, whereas when using the definition above, immersion is often defined by the range of technology used with the attempt of achieving presence (Cole, Crowle, Austwick, \& Henderson Slater, 2009; Steuer, 2006). As a result, this paper will also attempt to assess the quality of hardware used 
in each intervention and look to establish the extent to which presence was assessed in each study, in order to illustrate the level of immersion achieved in each intervention

Additionally, the concept of IVR has been misused frequently in the dementia and $\mathrm{MCl}$ literature to describe the use of any virtual environment, even in a nonimmersive environment. For the purpose of our study we regarded articles as utilising IVR if the authors made an attempt to create an immersive experience using the items in Table 1, but not necessarily utilising a head-mounted display (HMD), as long as alternative attempts to visually immerse the subject were made.

We devised a simple scoring method to assess the level of immersion through the use and availability of hardware for the intervention (Table 2). As the experience of 'presence' is more subjective, we were unable to objectively assess this but looked at each article to appraise the extent to which they sought to establish participant 'presence'. Haptic feedback, in this case, is the creation of a simulated touch experience, delivered through vibrations or other kinetic movements on skin (Okamura, 2009).

Table 2: Immersion scoring system

\subsection{Theoretical Basis of Intervention}

When developing novel medications, the mechanism of action is one of the first aspects that is considered and analysed. However it is widely acknowledged that clinical IVR literature rarely discusses theoretical aspects of mechanisms of action or 
how IVR theory applies to the problem being investigated (Garrett et al., 2018). We will also assess the extent to which theory on cognition and the interplay of IVR and the relevant intervention has been considered in developing each intervention.

\subsection{Data synthesis}

We intended to perform a meta-analysis if there was sufficient suitable data, or otherwise conduct a narrative synthesis of the included studies. 


\section{Results}

\subsection{Study Selection}

Our search identified a total of 2824 citations, Figure 1 breaks down the sources of obtained articles. 175 articles remained that were primary studies addressing virtual reality and dementia/MCl. These articles were broken down into 4 groups, (1) Papers addressing cognition and other dementia/MCl outcomes, (2) Papers addressing Physical rehabilitation only, (3) VR as a modality of assessment, (4) other. 69 articles specifically addressed VR as a modality of assessing and diagnosing dementia or cognitive impairment. 70 articles specifically addressed physical rehabilitation only, most of which looked at gait abnormalities in Parkinson's

Disease. Fourteen articles addressed two or more of these groups (but not cognition in dementia). Whilst nine articles did not address any of these topics, most of these focused on training healthcare professionals or family members to manage or understand dementia or $\mathrm{MCl}$. At this stage we noted that most, if not all, articles would not meet our criteria to be determined as 'fully immersive'. As a result, articles were included if they we established a clear attempt was made to immerse the participant in the intervention, such as isolating the participant in a darkened room, or using enlarged screens to deliver the intervention.

13 articles remained for potential inclusion. Out of these 13 articles, four were determined to use non-immersive virtual reality and therefore excluded. Four other articles included all older adults in their participant group, and not just people with $\mathrm{MCl}$ or dementia. Due to the heterogeneity of included articles, we were unable to 
conduct a meta-analysis of the included data, as a result descriptive analysis was conducted. Studies excluded participants with severe medical or psychological conditions or had some sort of disabling neurosensory conditions making it difficult to deliver therapies. Of the four studies excluded because the interventions were judged to be non-immersive, one of these studies utilised augmented reality delivered via a phone app and therefore we judged not to give an immersive experience (Bormans, Roe, \& De Wachter, 2016). Three of these studies solely used an iPad-based exer-game used in participants living rooms, deeming this experience un-immersive (Anderson-Hanley et al., 2018; Lee, Lee, \& Song, 2015; Wall et al., 2018 ) .

\subsection{Study Quality and Risk of Bias within studies}

Most studies utilised extremely small samples sizes $(n=1$ to $n=57)$. However, both randomised-controlled pilot trials were methodologically sound when assessed against the CASP critical appraisal checklist (Maggio et al., 2018; Optale et al., 2010). It was more difficult to assess the non-controlled studies, and based on the aims of the studies, inclusion of a control group would have been useful to clarify and demonstrate outcomes. The two studies that blinded study personnel were not explicit about how this was done. The appendices show CASP quality appraisal with additional appraisal for certain bias risks described in the supplementary material.

Figure 1 PRISMA Chart demonstrating the screening process of papers in the systematic review 


\subsection{Description of Included Articles}

Only a small number of studies were included based on inclusion and exclusion criteria (Maggio et al., 2018; Manera et al., 2016; Moyle, Jones, Dwan, \& Petrovich, 2018; Optale et al., 2010; White \& Moussavi, 2016). As a result, we did not exclude any studies based on their quality or risk of bias. A lower threshold for immersion was also accepted, with articles using semi-IVR techniques accepted for inclusion in this review. All five articles were included for final analyses. One article originated from Australia, one from France, two from Italy and one from Canada. Two articles were randomised-controlled feasibility studies, two articles were non-controlled pilot trials and one article described a case-study of an intervention with one participant. Most included studies were published between 2016 and 2018, with only one article published in 2010. Of the studies that used a control condition, two used face-to-face therapy and one used a paper-based activity.

The mean length of time the participants received the intervention for was 58 days (range $n=1-183$ ), with some participants only receiving one session in total and some receiving three sessions per week for over three months. In four out of the five studies, all participants completed the intervention, this is apart from Optale et al., where five out of the 36 participants dropped out of the study before the intervention was complete (three participants died and two left the home) (Optale et al., 2010). Figure 2 shows a summary of the characteristics of included studies, with the supplementary data in appendix B giving a detailed breakdown of each article. 


\subsection{Participants and Baseline Cognitive Function}

A total of 119 participants were included across the five included studies (range 157). Two studies utilised the Mini-Mental State Examination (MMSE) as a key aspect for inclusion of participants to the study and/or baseline measurement of participants. Maggio et al., included participants with an MMSE ranging between 11 and 26 whilst Manera et al., included patients with an MMSE ranging between 16 and 28, having a slightly higher threshold of cognitive function for inclusion (Maggio et al., 2018; Manera et al., 2016). Optale et al., utilised a Verbal Story Recall (VSR) test to include participants, with participants included if they scored below 15.76 (Optale et al., 2010). Moyle at al., and White et al., used documented diagnoses as part of their inclusion criteria, using diagnosis of dementia and $\mathrm{MCl}$ respectively, where White et al. also recorded a Montreal Cognitive Assessment (MoCA) score of 24 on their single patient (Moyle et al., 2018; White \& Moussavi, 2016). No studies reported recruitment response rates.

Mean age of participants was $76.8,54 \%$ were female and $46 \%$ male. Moyle and White did not report the level of education of their participants (Moyle et al., 2018; White \& Moussavi, 2016). Maggio reported that $25 \%$ of participants received a primary school education, $55 \%$ high school/secondary and $20 \%$ had a university education. Optale stated that participants were standardised for education without stating the levels of education (Optale et al., 2010). Manera reported $1.8 \%$ of participants had an unknown level of education, $1.8 \%$ had no education, $33 \%$ 
described only primary education, $32 \%$ were educated to secondary level and $32 \%$ to university level (Manera et al., 2016).

\subsection{Use of IVR interventions}

Two studies used full IVR therapy and three studies used a semi-immersive approach to VR therapy. A broad range of hardware was utilised throughout the studies. Two studies utilised a HMD (Optale et al., 2010; White \& Moussavi, 2016). Three studies utilised large screens or 'video-walls' as their visual hardware, two of these screens were considered 'interactive' (Maggio et al., 2018; Manera et al., 2016; Moyle et al., 2018). Two studies utilised infrared motion sensors to track participants' movements (Maggio et al., 2018; Moyle et al., 2018). One study used a wireless mouse to track motions (Manera et al., 2016). The remaining studies used HMD motion tracking, and Optale et al. also used a modified office swivel chair equipped with trackers to track and feedback movement (Optale et al., 2010; White \& Moussavi, 2016). It appeared all studies utilised some form of audio-feedback, however only Optale et al., and White et al., appeared to use headphones to deliver this feedback, the rest used external speakers. No studies utilised haptic feedback as part of their hardware suite. The mean immersion score, based on the criteria set out in Table 1, was 7.4 out of 10 (range 5-9). None of the studies described whether they assessed the level of presence described by their participants.

It is important to note that in one study, authors described external factors that may have affected immersion and thus participants' presence in their virtual environment (Moyle et al., 2018). The study took place in two separate care homes and the 
authors note that results were very different by facility. One facility offered a quiet dark room with dimmed lighting with little background noise to conduct the intervention, whereas the other facility offered a room near a social room with a budgerigar present.

Interventions were extremely heterogeneous in their theme, task and goals. Maggio et al., utilised a variety of VR based games as the basis of their intervention. Each game targeted a specific domain of cognitive function, for example a game focused on memory training asking participants to memorise and recall objects seen in a previous virtual environment. No other study took a cognitive domain-specific approach. White et al. developed a memory game, asking participants to memorise and identify 'target windows' in a virtual house, however this memory game appears to have been utilised to improve all cognitive domains - assessing improvements using MoCA or MMSE. No other interventions were developed in the White paper to address other cognitive domains. Manera et al. developed a task aimed at differentiating colours and patterns, of varying difficulties. Optale and Moyle developed a VR scenario for participants to navigate through, with Optale et al. allowing participants to activate film clips as they navigate their path. Studies gave varying detail in explaining theoretical considerations underlying the development of their VR interventions, which mostly focused on the multi-sensory immersion freeing the participant from external distraction.

Maggio et al., stipulated that VR provides multisensory stimulation to create a realistic environment and improve motivation and the adhesion of participants to rehabilitation, whilst grounding each individual activity in a different cognitive domain. 
Manera et al., described that VR creates a more realistic environment, ability for faster feedback and a greater degree of personalisation than paper tasks. They went further when describing their task design was based on the principles of the classical cancellation task, employed for instance in the Attention Process Training — an intervention designed to rehabilitate attentional problems in people with brain injuries. Optale described that VR therapy 'frees the patient' from external distraction and encourages selective attention, without fully outlining the proposed mechanisms or grounding of their specific tasks. White et al., stipulated that navigational training tasks may reduce Alzheimer's Disease pathology - justifying their task design without a specific focus on the use of VR. The theoretical grounding behind the Moyle et al. intervention was not clearly described.

\subsection{Acceptability}

Two studies focused on acceptability of IVR therapy; Manera et al and Moyle et al.,. Manera et al., reported that participants were highly satisfied with IVR therapy and reported low levels of anxiety and fatigue. Participants were also more satisfied with the IVR condition compared to a paper-based control condition, however reported feeling less secure in using the IVR condition. Moyle et al., reported statistically significant lower apathy after using the IVR condition and participants appeared to express more enjoyment having used the IVR condition compared with baseline participant data from a different cohort of people with dementia (1.4 vs $2.8 p=0.008$ ) (Moyle et al., 2018). Maggio et al., White et al., and Optale did not report data on acceptability. 


\subsection{Feasibility and Potential Effectiveness}

Three studies recorded estimates for the effects based on cognitive functioning. Maggio et al., and Optale et al., described statistically significant improvements in MMSE scores $(+2.15(p=0.014)$ after two months of three-weekly sessions of intervention and $+0.74(\mathrm{p}=0.044)$ after six months of three-weekly sessions respectively), whilst White et al. described no statistically significant improvements in the participant's MoCA score, offering three weekly sessions for seven weeks. Maggio et al., and Optale et al., also described improvements in their participants general depression scores along with MMSE and VSR (see summary table) (GDS = $-0.23(p=0.812)$ and $-1.05(p=0.025)$ respectively) (Maggio et al., 2018; Optale et al., 2010). The White et al. study offered no objective improvements in cognitive scoring of their single participant, they however describe some subjective improvements observed by the participant's wife (White \& Moussavi, 2016). Additionally, Moyle et al., did not use standardised global cognitive scoring systems to assess improvements in cognitive domains however they did report improvements in alertness $(p<.001)$ based on observed emotional rating scale scores, akin to the cognitive domain of attention (Lindsley, 1988). Manera et al., did not report changes in cognitive functioning.

\section{Discussion}

\subsection{Principal Findings}

We are unable to conclude whether the use of IVR for improving cognitive function in dementia and $\mathrm{MCl}$ is effective. Some data suggests IVR is acceptable to selected 
populations of people with dementia/MCI, with low attrition rates and some evidence suggesting people with dementia prefer and enjoy the use of Virtual Reality-based interventions (Maggio et al., 2018; Manera et al., 2016; Moyle et al., 2018; Optale et al., 2010). However, due to small sample sizes it is important to highlight that these additional findings are not definitive either.

Despite this, there remains promise and incentives for future research, including well-designed RCTs with representative populations. The current studies in this field lay the groundwork and highlight opportunities to develop and rigorously test further interventions in this field.

\subsection{Limitations}

Defining 'Immersive Virtual Reality'

A number of studies encountered during the search process utilised definitions of IVR that did not meet either criteria to be Virtual Reality, or were 'non-immersive', as defined earlier in this paper (see 2.6). This phenomenon is not unique to the field of dementia/MCl and not unique to healthcare (Garrett et al., 2018). In computer science, commercial spheres, and in the media, many define virtual reality as an ability to combine software with hardware to create a fully immersive experience (Rubin, 2018). However, the term 'virtual reality' in healthcare has been used for over two decades to describe both non-immersive and immersive experiences that create any version of an alternate reality (Riva, Bacchetta, Baruffi, Rinaldi, \& Molinari, 1999). Although it is not possible to correct this disparity in definitions 
retrospectively, it is important to emphasize the need for future articles to utilise standardised definitions of IVR. Li et al. offer an extensive definition of immersive virtual reality through the hardware used to create this experience (Li et al., 2011).

Garrett et al. highlight the importance of the concept of 'presence' in virtual reality, referring to the extent to which users feel immersed in the world created by the components of software and hardware (Garrett et al., 2018). Interestingly, presence was not addressed in our included studies. The level of presence is subjective, and dependant on user experience, and therefore may not be included in a definition of IVR, however it is essential future studies assess the level presence experienced by users. This will allow for more direct comparison of IVR interventions, and to understand the direct additional benefit of the 'immersive' experience virtual reality can offer over other simulated interventions. Assessment methods for presence have been developed such as the iGroup Presence Questionnaire (Scuhbert T, 2018). However, this questionnaire has not yet been validated for use with people with dementia or MCl (Scuhbert T, 2018).

As described in the results, two studies utilised a HMD (Optale et al., 2010; White \& Moussavi, 2016). Three studies utilised large screens or 'video-walls' as their visual hardware, two of these screens were considered 'interactive' (Maggio et al., 2018; Manera et al., 2016; Moyle et al., 2018). As cheaper HMD options come onto the market, such as Google Cardboard, costing as little as 10USD to convert a smartphone into a HMD, it is important to highlight the somewhat prohibitive cost of utilising video walls, costing over 10,000USD (Goh et al., 2018). Future studies should consider these barriers to access for IVR interventions when developing their 
own interventions (Ambron, Miller, Kuchenbecker, Buxbaum, \& Coslett, 2018; Massetti et al., 2018).

Heterogeneity of Interventions

It is important to highlight the heterogeneity in hardware, software and the specific types of training used in our included studies. This makes it difficult to draw specific conclusions about the benefits of IVR for people with dementia/MCI. It could be speculated that if a specific game is deemed effective or acceptable, it is unclear if a specific part of the hardware or the whole experience is what benefits the individuals. Quantifying this is difficult without control conditions for these factors, which three of the five included papers attempted to do by creating 'paper' versions of each game delivered in virtual reality (Maggio et al., 2018; Manera et al., 2016; Optale et al., 2010). It is however more difficult to create a control condition for the software used in trials, as the immersive style of the experience may also influence the efficacy of the intervention. The lack of differentiation for content delivery is not a unique issue to the emerging field of IVR for people with dementia or $\mathrm{MCl}$, but rather a problem seen throughout IVR healthcare developments (Garrett et al., 2018). However, this may mean that more than one control is needed to demonstrate the efficacy of IVR in in a randomised-control trial. One paper-based study simulating the content of the intervention and one computer-based study simulating the content of the intervention without immersive elements. This will allow for greater external validity and true demonstration of the benefits of IVR. 
An additional challenge is presented by rapid development of IVR technology. Large differences in software and hardware availability exist, dramatically altering the experience of participants in studies even just one year apart (Faber, Patterson, \& Bremer, 2013; Garrett et al., 2014; Parsons \& Rizzo, 2008). This means it is fundamentally important for researchers to clearly document the year and version of each piece of hardware and software used, to allow for greater external validity something that was not uniformly done well across the papers included in our review. We attempted to compare hardware by using a simple scoring system for the components of hardware used in the interventions. However, more detailed reporting of hardware components involved in IVR interventions would contribute to greater external validity.

Our review highlights a challenge specific to dementia and other complex neurological conditions. The domains affected by dementia and mild cognitive impairment are broad and just as multiple activities (in an MMSE or MoCA) are used to assess different domains, varying therapeutic activities may be needed to combat the degeneration of varying cognitive domains ("Abbreviated Mental Test Score (AMTS)," 1993; Creavin et al., 2016; Nasreddine et al., 2005). Only one of our five studies provided a clear rationale and breakdown of the activities in their intervention and their links and impact on specific cognitive domains, whilst an additional study focused on the cognitive domain of memory (Maggio et al., 2018; White \& Moussavi, 2016). To improve external validity in future studies, it is important that a clear rationale behind specific games and interventions is explained, including which cognitive domains are targeted and how this might map onto real-life functioning and clinical outcomes for participants. The lack of theoretical basis of interventions also 
appears to be an issue in the wider literature surrounding clinical IVR, for example when describing the mechanism of pain relief achieved by IVR (Garrett et al., 2018).

Acceptability and Ethics of true IVR

As discussed, full IVR involves the use of HMDs (Huygelier et al., 2019). Two issues arise in their use. Firstly, some hypothesize that the use of HMDs may be generally unacceptable to the older population, with this technology being unfamiliar and potentially considered invasive. The second issue that arises in populations with more severe cognitive impairment, is an issue of consent, especially if HMDs are considered an invasive use of technology. A recent study study of 76 older, noncognitively impaired patients, suggested that after first use, older people's attitudes towards HMDs and IVR changes from neutral to positive and reported mnimal cyber sickness (Huygelier et al., 2019). The findings suggest that after first use, older people's attitudes towards HMDs and IVR changed from neutral to positive, and they reported minimal cyber sickness. The two studies that used HMDs with cognitively impaired populations were both included in this review (Optale \& White). White et al reported a case study, and Optale et al. used the HMD technology available in 2010, which may now be considered out of date. As such, no concise conclusions can be drawn, yet there seems to be an indication that it may be acceptable.

The ethical challenges of administering IVR who are unable to consent but may benefit from the technology is complex. The benefits from HMDs fully immersing an individual in a different environment may also be considered potentially harmful, 
removing patients from an environment that they may be more familiar with and potentially having unpredictable, disorientating and distressing effects in severe cognitive impairment. Additionally the physical strapping of the HMD to an individual's head may be considered ethically unpalatable.

\section{Challenges in disseminating IVR technology}

One the key barriers to conducting research with IVR technology and subsequent implementation are the costs involved. The current average cost of the top selling VR headsets is $£ 382$ (\$464) not including the additional computers or gaming devices needed to operate some devices (Greenwald, 2019). The costs associated with developing the software involved can be many multiples greater than the cost of the hardware. This may prohibit those attempting to develop and trial new interventions, especially in academic environments given the high rate of obsolescence of new technology (World Economic Forum, 2017). This may be overcome by forming new collaborations with games companies who have the resources to develop high-quality IVR interventions and the means to access consumers quickly once the interventions have been iterated and validated by academic centres. . If IVR based therapies are proven to be effective and useful for those with dementia attempts have to be made to mitigate any associated costs for patients. 


\subsection{Research Recommendations}

Future researchers should:

- ensure their interventions are fully immersive

- study the extent to which participants felt immersed in their environment

- utilise the latest IVR technology clearly document the version of technology used

- ensure adequate controls are present, to control for content of intervention and method of delivery (i.e. a paper-based control may not be enough to demonstrate that IVR is the superior method of delivery)

IVR studies should in addition be published without delay, to reduce risk of obsolescence by the time the study reaches mass readership

\section{Conclusions}

Only a small number of studies with small samples and methodological limitations have been published using IVR in dementia. It is therefore difficult to draw conclusions other than that more evidence is needed to demonstrate the use, acceptability and effectiveness of IVR in dementia and $\mathrm{MCI}$. It is important to learn quickly from the gaps present in the published literature, highlighting a need for a universally accepted definition of immersive virtual reality, and more robust clinical trials, utilising technology that is already available to consumers internationally. 


\section{Reference List}

Abbreviated Mental Test Score (AMTS). (1993). Occas Pap R Coll Gen Pract(59), 28.

Alzheimer's Society. (2014). Dementia UK report. Retrieved from https://www.alzheimers.org.uk/about-us/policy-and-influencing/dementia-ukreport?documentID=2759

Ambron, E., Miller, A., Kuchenbecker, K. J., Buxbaum, L. J., \& Coslett, H. B. (2018). Immersive Low-Cost Virtual Reality Treatment for Phantom Limb Pain: Evidence from Two Cases. Front Neurol, 9, 67. doi:10.3389/fneur.2018.00067

Anderson-Hanley, C., Stark, J., Wall, K. M., VanBrakle, M., Michel, M., Maloney, M., ... Kramer, A. F. (2018). The interactive Physical and Cognitive Exercise System (iPACES): effects of a 3-month in-home pilot clinical trial for mild cognitive impairment and caregivers. (1178-1998 (Electronic)).

Bannan, N., \& Montgomery-Smith, C. (2008). 'Singing for the brain': reflections on the human capacity for music arising from a pilot study of group singing with Alzheimer's patients. J R Soc Promot Health, 128(2), 73-78. doi: $10.1177 / 1466424007087807$

Barr, B., Bambra, C., \& Whitehead, M. (2014). The impact of NHS resource allocation policy on health inequalities in England 2001-11: longitudinal ecological study. Bmj, 348, g3231. doi:10.1136/bmj.g3231 
Bashiri, A., Ghazisaeedi, M., \& Shahmoradi, L. (2017). The opportunities of virtual reality in the rehabilitation of children with attention deficit hyperactivity disorder: a literature review. Korean J Pediatr, 60(11), 337-343. doi:10.3345/kjp.2017.60.11.337

Benoit, M., Guerchouche, R., Petit, P. D., Chapoulie, E., Manera, V., Chaurasia, G., . . Robert, P. (2015). Is it possible to use highly realistic virtual reality in the elderly? A feasibility study with image-based rendering. Neuropsychiatr Dis Treat, 11, 557-563. doi:10.2147/ndt.S73179

Bormans, K., Roe, K., \& De Wachter, D. (2016). Virtual memory palaces to improve quality of life in Alzheimer's disease. Annual Review of CyberTherapy and Telemedicine, 14, 227-232.

Bowman, D. A., \& McMahan, R. P. (2007). Virtual Reality: How Much Immersion Is Enough? Computer, 40(7), 36-43. doi:10.1109/MC.2007.257

Cano Porras, D., Siemonsma, P., Inzelberg, R., Zeilig, G., \& Plotnik, M. (2018). Advantages of virtual reality in the rehabilitation of balance and gait: Systematic review. Neurology, 90(22), 1017-1025. doi:10.1212/wnl.0000000000005603

Carrion, C., Folkvord, F., Anastasiadou, D., \& Aymerich, M. (2018). Cognitive Therapy for Dementia Patients: A Systematic Review. Dement Geriatr Cogn Disord, 46(1-2), 1-26. doi:10.1159/000490851 
Chien, P. F., Khan, K. S., \& Siassakos, D. (2012). Registration of systematic reviews: PROSPERO. Bjog, 119(8), 903-905. doi:10.1111/j.14710528.2011.03242.x

Cipresso, P., Giglioli, I. A. C., Raya, M. A., \& Riva, G. (2018). The Past, Present, and Future of Virtual and Augmented Reality Research: A Network and Cluster Analysis of the Literature. Front Psychol, 9, 2086. doi:10.3389/fpsyg.2018.02086

Cohen-Mansfield, J., Thein, K., Dakheel-Ali, M., \& Marx, M. S. (2010). The underlying meaning of stimuli: Impact on engagement of persons with dementia. Psychiatry Res, 177(1-2), 216-222.

doi:10.1016/j.psychres.2009.02.010

Cole, J., Crowle, S., Austwick, G., \& Henderson Slater, D. (2009). Exploratory findings with virtual reality for phantom limb pain; from stump motion to agency and analgesia. Disability and Rehabilitation, 31(10), 846-854. doi:10.1080/09638280802355197

Creavin, S. T., Wisniewski, S., Noel-Storr, A. H., Trevelyan, C. M., Hampton, T., Rayment, D., . . C Cullum, S. (2016). Mini-Mental State Examination (MMSE) for the detection of dementia in clinically unevaluated people aged 65 and over in community and primary care populations. Cochrane Database Syst Rev(1), Cd011145. doi:10.1002/14651858.CD011145.pub2 
Dashnaw Stiles, L. A. (2001). Animal-assisted therapy with children and the elderly : a critical review. Available from http://worldcat.org /z-wcorg/ database.

Dockx, K., Bekkers, E. M., Van den Bergh, V., Ginis, P., Rochester, L., Hausdorff, J. M., .. . Nieuwboer, A. (2016). Virtual reality for rehabilitation in Parkinson's disease. Cochrane Database Syst Rev, 12, Cd010760. doi:10.1002/14651858.CD010760.pub2

Ernsting, C., Dombrowski, S. U., Oedekoven, M., JL, O. S., Kanzler, M., Kuhlmey, A., \& Gellert, P. (2017). Using Smartphones and Health Apps to Change and Manage Health Behaviors: A Population-Based Survey. J Med Internet Res, 19(4), e101. doi:10.2196/jmir.6838

Faber, A. W., Patterson, D. R., \& Bremer, M. (2013). Repeated use of immersive virtual reality therapy to control pain during wound dressing changes in pediatric and adult burn patients. J Burn Care Res, 34(5), 563-568. doi:10.1097/BCR.0b013e3182777904

Forstmeier, S., \& Maercker, A. (2015). Motivational processes in mild cognitive impairment and Alzheimer's disease: results from the Motivational Reserve in Alzheimer's (MoReA) study. BMC Psychiatry, 15, 293. doi:10.1186/s12888015-0666-8

Garrett, B., Taverner, T., Gromala, D., Tao, G., Cordingley, E., \& Sun, C. (2018). Virtual Reality Clinical Research: Promises and Challenges. JMIR Serious Games, 6(4), e10839. doi:10.2196/10839 
Garrett, B., Taverner, T., Masinde, W., Gromala, D., Shaw, C., \& Negraeff, M. (2014). A rapid evidence assessment of immersive virtual reality as an adjunct therapy in acute pain management in clinical practice. Clin J Pain, 30(12), 1089-1098. doi:10.1097/ajp.0000000000000064

Goh, R. L. Z., Kong, Y. X. G., McAlinden, C., Liu, J., Crowston, J. G., \& Skalicky, S. E. (2018). Objective Assessment of Activity Limitation in Glaucoma with Smartphone Virtual Reality Goggles: A Pilot Study. Trans/ Vis Sci Technol, 7(1), 10. doi:10.1167/tvst.7.1.10

Greenwald, W. (2019, 1 March 2019). The Best VR (Virtual Reality) Headsets for 2019.

Hugo, J., \& Ganguli, M. (2014). Dementia and cognitive impairment: epidemiology, diagnosis, and treatment. Clin Geriatr Med, 30(3), 421-442. doi:10.1016/j.cger.2014.04.001

Huygelier, H., Schraepen, B., van Ee, R., Vanden Abeele, V., \& Gillebert, C. R. (2019). Acceptance of immersive head-mounted virtual reality in older adults. Scientific Reports, 9(1), 4519. doi:10.1038/s41598-019-41200-6

Kim, H. K., Park, J., Choi, Y., \& Choe, M. (2018). Virtual reality sickness questionnaire (VRSQ): Motion sickness measurement index in a virtual reality environment. App/ Ergon, 69, 66-73. doi:10.1016/j.apergo.2017.12.016 
Knopman, D. S., \& Petersen, R. C. (2014). Mild cognitive impairment and mild dementia: a clinical perspective. Mayo Clin Proc, 89(10), 1452-1459. doi:10.1016/j.mayocp.2014.06.019

Lee, N. Y., Lee, D. K., \& Song, H. S. (2015). Effect of virtual reality dance exercise on the balance, activities of daily living, and depressive disorder status of Parkinson's disease patients. (0915-5287 (Print)).

Leone, E., Piano, J., Deudon, A., Alain, B., Wargnier, A.-M., Balard, P., . . . Dechamps, A. (2012). "What are you interested in?"-A survey on 601 nursing homes residents activities interests (Vol. 01).

Li, A., Montano, Z., Chen, V. J., \& Gold, J. I. (2011). Virtual reality and pain management: current trends and future directions. Pain Manag, 1(2), 147157. doi:10.2217/pmt.10.15

Lin, Y., Tudor-Sfetea, C., Siddiqui, S., Sherwani, Y., Ahmed, M., \& Eisingerich, A. B. (2018). Effective Behavioral Changes through a Digital mHealth App: Exploring the Impact of Hedonic Well-Being, Psychological Empowerment and Inspiration. JMIR Mhealth Uhealth, 6(6), e10024. doi:10.2196/10024

Lindsley, D. B. (1988). Activation, Arousal, Alertness, and Attention. In J. A. Hobson (Ed.), States of Brain and Mind (pp. 1-3). Boston, MA: Birkhäuser Boston.

Maggio, M. G., De Cola, M. C., Latella, D., Maresca, G., Finocchiaro, C., La Rosa, G., . . Calabro, R. S. (2018). What About the Role of Virtual Reality in 
Parkinson Disease's Cognitive Rehabilitation? Preliminary Findings From a Randomized Clinical Trial. J Geriatr Psychiatry Neurol, 31(6), 312-318. doi:10.1177/0891988718807973

Manera, V., Chapoulie, E., Bourgeois, J., Guerchouche, R., David, R., Ondrej, J., . . . Robert, P. (2016). A Feasibility Study with Image-Based Rendered Virtual Reality in Patients with Mild Cognitive Impairment and Dementia. PLoS One, 11(3), e0151487. doi:10.1371/journal.pone.0151487

Massetti, T., da Silva, T. D., Crocetta, T. B., Guarnieri, R., de Freitas, B. L., Bianchi Lopes, P., ... de Mello Monteiro, C. B. (2018). The Clinical Utility of Virtual Reality in Neurorehabilitation: A Systematic Review. J Cent Nerv Syst Dis, 10, 1179573518813541. doi:10.1177/1179573518813541

Methley, A. M., Campbell, S., Chew-Graham, C., McNally, R., \& Cheraghi-Sohi, S. (2014). PICO, PICOS and SPIDER: a comparison study of specificity and sensitivity in three search tools for qualitative systematic reviews. BMC Health Serv Res, 14, 579. doi:10.1186/s12913-014-0579-0

Moher, D., Liberati, A., Tetzlaff, J., \& Altman, D. G. (2009). Preferred reporting items for systematic reviews and meta-analyses: the PRISMA statement. PLoS Med, 6(7), e1000097. doi:10.1371/journal.pmed.1000097

Moyle, W., Jones, C., Dwan, T., \& Petrovich, T. (2018). Effectiveness of a Virtual Reality Forest on People With Dementia: A Mixed Methods Pilot Study. Gerontologist, 58(3), 478-487. doi:10.1093/geront/gnw270 
Nasreddine, Z. S., Phillips, N. A., Bedirian, V., Charbonneau, S., Whitehead, V., Collin, I., ... Chertkow, H. (2005). The Montreal Cognitive Assessment, MoCA: a brief screening tool for mild cognitive impairment. J Am Geriatr Soc, 53(4), 695-699. doi:10.1111/j.1532-5415.2005.53221.x

Okamura, A. M. (2009). Haptic feedback in robot-assisted minimally invasive surgery. Curr Opin Urol, 19(1), 102-107. doi:10.1097/MOU.0b013e32831a478c

Olk, B., Dinu, A., Zielinski, D. J., \& Kopper, R. (2018). Measuring visual search and distraction in immersive virtual reality. $R$ Soc Open Sci, 5(5), 172331. doi:10.1098/rsos.172331

Optale, G., Urgesi, C., Busato, V., Marin, S., Piron, L., Priftis, K., . . Bordin, A. (2010). Controlling memory impairment in elderly adults using virtual reality memory training: a randomized controlled pilot study. Neurorehabil Neural Repair, 24(4), 348-357. doi:10.1177/1545968309353328

Parsons, T. D., \& Rizzo, A. A. (2008). Affective outcomes of virtual reality exposure therapy for anxiety and specific phobias: a meta-analysis. J Behav Ther Exp Psychiatry, 39(3), 250-261. doi:10.1016/j.jbtep.2007.07.007

Prince, M., Ali, G. C., Guerchet, M., Prina, A. M., Albanese, E., \& Wu, Y. T. (2016). Recent global trends in the prevalence and incidence of dementia, and survival with dementia. Alzheimers Res Ther, 8(1), 23. doi:10.1186/s13195016-0188-8 
Rash, C. E. (2008). A 25-year retrospective review of visual complaints and illusions associated with a monocular helmet-mounted display. Displays, 29(2), 70-80. doi:https://doi.org/10.1016/j.displa.2007.09.011

Riva, G. (2002). Virtual reality for health care: the status of research. Cyberpsychol Behav, 5(3), 219-225. doi:10.1089/109493102760147213

Riva, G., Bacchetta, M., Baruffi, M., Rinaldi, S., \& Molinari, E. (1999). Virtual reality based experiential cognitive treatment of anorexia nervosa. J Behav Ther Exp Psychiatry, 30(3), 221-230.

Rizzo, A., \& Kim, G. J. (2005). A SWOT analysis of the field of virtual reality rehabilitation and therapy \%J Presence: Teleoper. Virtual Environ. 14(2), 119146. doi:10.1162/1054746053967094

Rubin, P. (2018, 5/25/18). The Wired Guide to Virtual Reality. Retrieved from https://www.wired.com/story/wired-guide-to-virtual-reality/

Schwarz, S., Froelich, L., \& Burns, A. (2012). Pharmacological treatment of dementia. Curr Opin Psychiatry, 25(6), 542-550. doi:10.1097/YCO.0b013e328358e4f2

Scuhbert T, R. H., Friedmann F. (2018). iGroup Presence Questionnaire (IPQ) Overview,. Retrieved from http://www.igroup.org/pq/ipq/index.php 
Silveri, M. C., Reali, G., Jenner, C., \& Puopolo, M. (2007). Attention and memory in the preclinical stage of dementia. J Geriatr Psychiatry Neurol, 20(2), 67-75. doi:10.1177/0891988706297469

Slater, M., \& Wilbur, S. (1997). A Framework for Immersive Virtual Environments (FIVE): Speculations on the Role of Presence in Virtual Environments. Presence: Teleoperators and Virtual Environments, 6(6), 603-616. doi:10.1162/pres.1997.6.6.603

Steuer, J. (2006). Defining Virtual Reality: Dimensions Determining Telepresence. Journal of Communication, 42(4), 73-93. doi:10.1111/j.14602466.1992.tb00812.x \%J Journal of Communication

Wall, K. A.-O., Stark, J., Schillaci, A., Saulnier, E. T., McLaren, E., Striegnitz, K., . . . Anderson-Hanley, C. (2018

). The Enhanced Interactive Physical and Cognitive Exercise System (iPACES(TM) v2.0): Pilot Clinical Trial of an In-Home iPad-Based Neuro-Exergame for Mild Cognitive Impairment (MCI). LID - E249 [pii] LID - 10.3390/jcm7090249 [doi]. (2077-0383 (Print)).

White, P. J., \& Moussavi, Z. (2016). Neurocognitive Treatment for a Patient with Alzheimer's Disease Using a Virtual Reality Navigational Environment. J Exp Neurosci, 10, 129-135. doi:10.4137/jen.S40827 
Wimo, A., Winblad, B., \& Jonsson, L. (2010). The worldwide societal costs of dementia: Estimates for 2009. Alzheimers Dement, 6(2), 98-103. doi:10.1016/j.jalz.2010.01.010

World Economic Forum. (2017). Technology and Innovation for the Future of Production: Accelerating Value Creation.

York Health Economics Consortium. (2017). Overview of Systematic Reviews of Nonpharmacological Interventions for Dementia. York: University of York 
Figure 1 PRISMA Chart demonstrating the screening process of papers in the systematic review

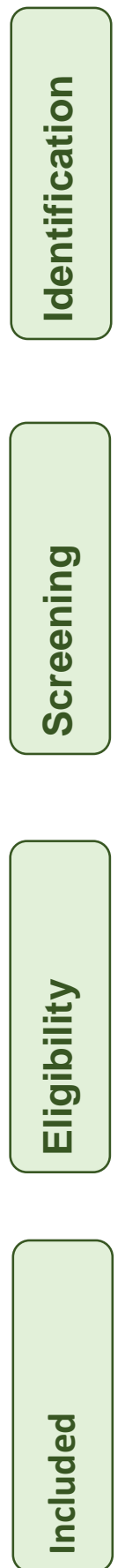

Records identified through
database searching
OVID $=170$
PubMed $=1579$
Psyclnfo $=338$
EMBase $=586$
CINAHL $=151$
(total $\mathbf{n}=\mathbf{2 8 2 4}$ )

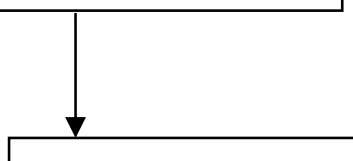

Records after duplicates removed

$(n=2136)$

Additional records identified through other sources $(\mathbf{n}=\mathbf{0})$

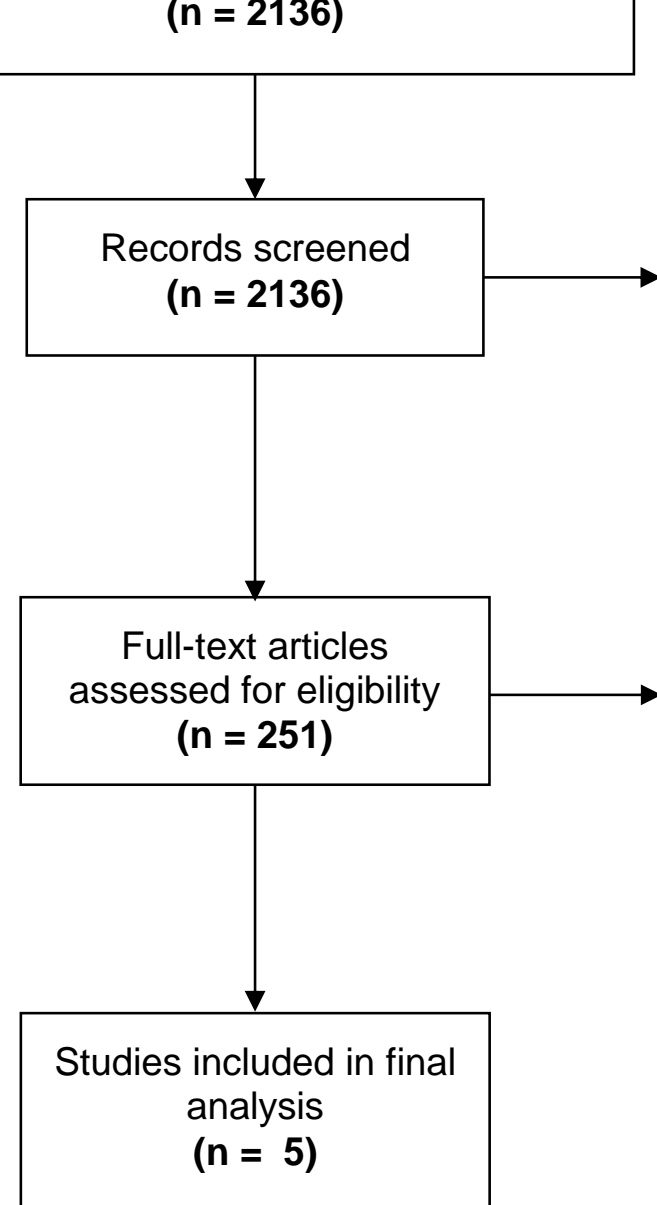

Records excluded Not related to Dementia or $\mathrm{VR}=924$

Not related to $\mathrm{VR}=833$

Related to VR but not dementia/MCl $=85$ Conference

Proceedings $=43$ ( $n=1885$ )

Full-text articles excluded, with reasons Not primary studies $=76$

(1) VR to assess and diagnose dementia $=69$

(2) VR for physical rehabilitation in non- $\mathrm{MCl}$ patients $=70$

Addressed both (1) and (2) $=14$

Did not address any specific VR topic $=9$ Non-immersive VR $=4$ Older participants not $\mathrm{MCl}=4$ ( $n=246$ ) 
Figure 2 A summary of characteristics of included studies

\begin{tabular}{|c|c|c|c|c|c|c|c|c|}
\hline Reference & Description & Methods & Participants & $\begin{array}{l}\text { Baseline } \\
\text { Measurements }\end{array}$ & Hardware & $\begin{array}{l}\text { Frequency } \\
\text { of } \\
\text { Intervention }\end{array}$ & Control & Outcomes \\
\hline $\begin{array}{l}\text { Maggio et al., } \\
2018 \\
\text { Italy }\end{array}$ & $\begin{array}{l}20 \text { patients with PD } \\
\text { undergoing } \\
\text { neurorehabilitation were } \\
\text { randomized, those in the } \\
\text { experimental group } \\
\text { received semi-immersive } \\
\text { virtual reality training with } \\
\text { BTS-N }\end{array}$ & $\begin{array}{l}\text { Randomised } \\
\text { controlled } \\
\text { Pilot Study }\end{array}$ & $\begin{array}{l}20 \text { patients with } \\
\text { Parkinson's Disease } \\
\text { Gender - } 10 \text { male, } 10 \\
\text { female } \\
\text { Mean Age }-69\end{array}$ & $\begin{array}{l}\text { (1) Hoehn Yahr <3 (2) } \\
\text { MMSE } 11-26\end{array}$ & $\begin{array}{l}\text { Infrared sensors, } \\
\text { workstation touch screen, } \\
\text { camera supports and web } \\
\text { cam. }\end{array}$ & $\begin{array}{l}\text { Three, one hour } \\
\text { sessions every } \\
\text { week for } 8 \text { weeks }\end{array}$ & $\begin{array}{l}\text { Face-to-face } \\
\text { therapy } \\
\text { sessions }\end{array}$ & $\begin{array}{l}\text { Estimates for } \\
\text { treatment effects } \\
\text { included: } \\
\text { MMSE }=+2.15 \\
(p=0.014) \\
\text { ACE-R }=+12.69 \\
(p=<0.0001) \\
\text { GDS }=-0.23(p=0.812)\end{array}$ \\
\hline $\begin{array}{l}\text { Manera et al., } \\
2016^{\text {(Manera et al., }} \\
\text { 2016) } \\
\text { USA }\end{array}$ & $\begin{array}{l}\text { The authors designed an } \\
\text { attentional task to train } \\
\text { selective and sustained } \\
\text { attention, and tested this } \\
\text { task in a single session }\end{array}$ & $\begin{array}{l}\text { Non- } \\
\text { controlled } \\
\text { feasibility } \\
\text { study }\end{array}$ & $\begin{array}{l}28 \text { participants with } \mathrm{MCl} \\
29 \text { participants with } \\
\text { Dementia } \\
\text { Gender }-25 \text { female, } 32 \\
\text { male } \\
\text { Mean Age }-75.65\end{array}$ & $\begin{array}{l}\text { MMSE 16-28 (baseline } \\
\text { apathy also measured) }\end{array}$ & $\begin{array}{l}\text { Barco OvervView OLSF- } \\
721 \text { full HD 3D } \\
\text { stereoscopic LED video } \\
\text { wall. } \\
\text { 3D LCD shutter glasses } \\
\text { Wireless mouse tracker }\end{array}$ & $\begin{array}{l}\text { One five minute } \\
\text { session with VR } \\
\text { condition, followed } \\
\text { by one five minute } \\
\text { session with paper } \\
\text { condition in a } \\
\text { randomised order }\end{array}$ & $\begin{array}{l}\text { No control, } \\
\text { however VR } \\
\text { compared to } \\
\text { Paper } \\
\text { condition }\end{array}$ & $\begin{array}{l}\text { Outcomes included: } \\
\text { To be highly satisfied } \\
\text { concerning the } \\
\text { experience (VR, M= } \\
8.6 / 10, \mathrm{SD}=1.7 ; \\
\text { paper: } \mathrm{M}=8.2 / 10, \mathrm{SD} \\
=2.3)\end{array}$ \\
\hline $\begin{array}{l}\text { Optale et al., } \\
2010^{\text {(Optale et al., }} \\
\text { 2010) } \\
\text { Italy }\end{array}$ & $\begin{array}{l}\text { The authors implemented } \\
\text { a VR training intervention } \\
\text { to try to lessen cognitive } \\
\text { decline and improve } \\
\text { memory functions. } \\
\text { Elderly residents of a rest } \\
\text { care facility who were } \\
\text { impaired on the Verbal } \\
\text { Story Recall Test either } \\
\text { to the experimental or the } \\
\text { control group. The EG } \\
\text { underwent } 6 \text { months of } \\
\text { VR memory training }\end{array}$ & $\begin{array}{l}\text { Randomised } \\
\text { controlled } \\
\text { Pilot Study }\end{array}$ & $\begin{array}{l}31 \text { participants with } \mathrm{MCl} \\
\text { Gender }-22 \text { female, } 9 \\
\text { male } \\
\text { Mean Age }-80 \text { mean } \\
\text { (31) }\end{array}$ & $\begin{array}{l}\text { Total score at the } \\
\text { Verbal Story Recall test } \\
\text { (below 15.76) }\end{array}$ & $\begin{array}{l}\text { Head-mounted display V6 } \\
\text { Headphone } \\
\text { Head-mounted motion } \\
\text { tracker } \\
\text { Joystick } \\
\text { Office swivel chair }\end{array}$ & $\begin{array}{l}3,30 \text {-minute } \\
\text { sessions per week } \\
\text { for } 3 \text { months } \\
\text { followed by } 2 \\
\text { sessions per week } \\
\text { for a further } 3 \\
\text { months (alternating } \\
\text { between auditory } \\
\text { and BR experience } \\
\text { sessions) }\end{array}$ & $\begin{array}{l}\text { Face-to-face } \\
\text { music therapy }\end{array}$ & $\begin{array}{l}\text { Estimates for effect } \\
\text { sizes include: } \\
\text { MMSE }=+4.46 \\
\text { ( } p=0.044) \\
\text { Verbal Story Recall }= \\
+1.02 \\
\text { GDS }=-1.05\end{array}$ \\
\hline $\begin{array}{l}\text { Moyle et al., } \\
2017^{\text {(Moyle et al., }} \\
\text { 2018) } \\
\text { Australia }\end{array}$ & $\begin{array}{l}\text { Ten residents with } \\
\text { dementia participated in } \\
\text { one facilitated VR- forest } \\
\text { session }\end{array}$ & $\begin{array}{l}\text { Non- } \\
\text { controlled } \\
\text { pilot study } \\
\text { with } \\
\text { qualitative } \\
\text { component }\end{array}$ & $\begin{array}{l}10 \text { participants with } \\
\text { dementia } \\
10 \text { family members } \\
9 \text { care staff } \\
\text { Gender - Male } 3 \\
\text { Female } 7 \\
\text { Mean Age - } 89(10)\end{array}$ & $\begin{array}{l}\text { Documented diagnosis } \\
\text { of dementia }\end{array}$ & $\begin{array}{l}\text { Large interactive screen } \\
\text { Xbox Kinect motion } \\
\text { sensors } \\
\text { Audio feedback }\end{array}$ & $\begin{array}{l}\text { One } 15 \text { minute } \\
\text { session }\end{array}$ & Not present & $\begin{array}{l}\text { Included: Participants } \\
\text { expressed significantly } \\
\text { more pleasure } 1.4 \text { vs } \\
2.8 p=0.008) \\
\text { And more Alertness } \\
(1.2 \text { vs } 2.4 p<0.001) \\
\text { compared with before } \\
\text { the intervention }\end{array}$ \\
\hline $\begin{array}{l}\text { White et al., } \\
2016^{\text {(White \& }} \\
\text { Moussavi, 2016) } \\
\text { Canada }\end{array}$ & $\begin{array}{l}\text { A man at the onset of } \\
\text { Alzheimer's was enrolled } \\
\text { in a cognitive treatment } \\
\text { program based upon } \\
\text { spatial navigation in VR }\end{array}$ & $\begin{array}{l}\text { Single case } \\
\text { study }\end{array}$ & $\begin{array}{l}\text { One participant with } \\
\mathrm{MCl} \\
\text { Gender - } 1 \text { male } \\
\text { Mean Age - } 74 \text { (1) }\end{array}$ & Score of 24 on MoCA & $\begin{array}{l}\text { Oculus Rift Dk2 (HMD) } \\
\text { Laptop }\end{array}$ & $\begin{array}{l}45 \text { minute training } \\
\text { sessions, three } \\
\text { times per week for } \\
7 \text { weeks }\end{array}$ & Not present & $\begin{array}{l}\text { No objective } \\
\text { improvement in MoCA }\end{array}$ \\
\hline
\end{tabular}


Table 1: Summary of search terms, utilising PICOS model

\begin{tabular}{|l|l|}
\hline Population & Dementia, Alzheimer's, Parkinson's \\
& Disease, Vascular Dementia, MCI/Mild \\
& Cognitive Impairment, Cognitive \\
& Impairment \\
\hline Intervention & Virtual Reality, Immersive Virtual \\
& Reality, 3D Environment, Simulated \\
& Environment, Augmented Reality \\
\hline Comparison & Any control (not specified in search) \\
\hline Outcome & Cognition, Cognitive Function, Cognitive \\
& Behaviour \\
\hline Study design & $\begin{array}{l}\text { Any design with measurement pre and } \\
\text { post-intervention (not specified in } \\
\text { search) }\end{array}$ \\
\hline
\end{tabular}


Table 2: Immersion scoring system

\begin{tabular}{|l|l|}
\hline Hardware Element & Score \\
\hline Visual Immersion & $\begin{array}{l}\text { (3) Head mounted display utilised in delivering therapy } \\
\text { (2) Visually Immersed via large screen } \\
\text { (1) Attempt to immerse mitigated by external } \\
\text { distractors or not stated }\end{array}$ \\
\hline Audio Immersion & $\begin{array}{l}\text { (3) Headphones utilised } \\
\text { (2) Sound produced from external speakers } \\
\text { (1) Not stated or no sound feedback }\end{array}$ \\
\hline Motor Immersion & $\begin{array}{l}\text { (3) Movement sensors and or limb movement trackers } \\
\text { utilised } \\
\text { (2) Trackpad utilised } \\
\text { (1) No motor tracking }\end{array}$ \\
\hline Haptic Feedback & $\begin{array}{l}\text { (1) Present } \\
\text { (0) Not present }\end{array}$ \\
\hline Total Maximum Score & 10 \\
\hline
\end{tabular}

\section{Appendix A: CASP Article Appraisal}

*These trials were not randomised controlled trials, and were not stated by the authors to be randomised controlled trials 


\begin{tabular}{|c|c|c|c|c|c|c|c|c|c|c|c|}
\hline $\begin{array}{l}\text { Paper } \\
\text { Reference }\end{array}$ & $\begin{array}{l}\text { 1. Did the } \\
\text { trial } \\
\text { address a } \\
\text { clearly } \\
\text { focused } \\
\text { issue? }\end{array}$ & $\begin{array}{l}\text { 2. Was the } \\
\text { assignment } \\
\text { of patients to } \\
\text { treatments } \\
\text { randomised? }\end{array}$ & $\begin{array}{l}\text { 3. Were all of } \\
\text { the patients } \\
\text { who entered } \\
\text { the trial } \\
\text { properly } \\
\text { accounted for } \\
\text { at its } \\
\text { conclusion? }\end{array}$ & $\begin{array}{l}\text { 4. Were } \\
\text { patients, } \\
\text { health } \\
\text { workers } \\
\text { and study } \\
\text { personnel } \\
\text { 'blind' to } \\
\text { treatment }\end{array}$ & $\begin{array}{l}\text { 5. Were } \\
\text { the } \\
\text { groups } \\
\text { similar at } \\
\text { the start } \\
\text { of the } \\
\text { trial? }\end{array}$ & $\begin{array}{l}\text { 6. Aside } \\
\text { from the } \\
\text { experimental } \\
\text { intervention, } \\
\text { were the } \\
\text { groups } \\
\text { treated } \\
\text { equally? }\end{array}$ & $\begin{array}{l}\text { 7. How large was the treatment } \\
\text { effect? }\end{array}$ & $\begin{array}{l}\text { 8. How precise } \\
\text { was the } \\
\text { estimate of the } \\
\text { treatment } \\
\text { effect? }\left(r^{2}\right)\end{array}$ & $\begin{array}{l}\text { 9. Can the } \\
\text { results be } \\
\text { applied to } \\
\text { the local } \\
\text { population, } \\
\text { or in your } \\
\text { context? }\end{array}$ & $\begin{array}{l}\text { 10. Were all } \\
\text { clinically } \\
\text { important } \\
\text { outcomes } \\
\text { considered? }\end{array}$ & $\begin{array}{l}\text { 11. Are the } \\
\text { benefits } \\
\text { worth the } \\
\text { harms and } \\
\text { costs? }\end{array}$ \\
\hline $\begin{array}{l}\text { Maggio et } \\
\text { al., } \\
2018^{\text {(Maggio et }} \\
\text { al., 2018) }\end{array}$ & Yes & Yes & Yes & Yes & Yes & Yes & $\begin{array}{l}\text { Estimates for treatment effects } \\
\text { included } \\
\text { MMSE }=+2.15(p=0.014) \\
\text { ACE-R }=+12.69(p=<0.0001) \\
\text { GDS }=-0.23(p=0.812)\end{array}$ & $\begin{array}{l}\text { Effect sizes } \\
\text { were above } 0.5 \\
\text { MMSE }=0.62 \\
\text { ACE-R }=0.95 \\
\text { GDS } 0.83\end{array}$ & Yes & $\begin{array}{l}\text { No, presence } \\
\text { not } \\
\text { considered }\end{array}$ & Yes \\
\hline $\begin{array}{l}\text { Manera et } \\
\text { al., } \\
2016 \text { (Manera et } \\
\text { al., 2016) }\end{array}$ & Yes & $\begin{array}{l}\mathrm{No}^{\star} \text {, however } \\
\text { patients were } \\
\text { randomly } \\
\text { allocated the } \\
\text { order in which } \\
\text { they received } \\
\text { the } \\
\text { intervention } \\
\text { and control }\end{array}$ & Yes & No & $\mathrm{No}^{*}$ & $\mathrm{No}^{*}$ & $\begin{array}{l}\text { For both the VR and the paper } \\
\text { conditions, participants reported: } \\
\text { To be highly satisfied concerning the } \\
\text { experience }(V R, M=8.6 / 10, S D=1.7 \text {; } \\
\text { paper: } \mathrm{M}=8.2 / 10, S D=2.3) \\
\text { Highly interested }(\mathrm{VR}, \mathrm{M}=8.0 / 10, \mathrm{SD} \\
=2.3 \text {; paper: } \mathrm{M}=7.9 / 10, \mathrm{SD}=2.2) \text {. } \\
\text { They reported }\end{array}$ & $\mathrm{N} / \mathrm{A}$ & $\begin{array}{l}\text { No, small } \\
\text { population } \\
\text { size and no } \\
\text { control }\end{array}$ & $\begin{array}{l}\text { No, although } \\
\text { it was a pilot } \\
\text { study may } \\
\text { have been } \\
\text { useful to } \\
\text { consider } \\
\text { changes in } \\
\text { cognition. } \\
\text { presence not } \\
\text { considered }\end{array}$ & Yes \\
\hline $\begin{array}{l}\text { Optale et } \\
\text { al., } \\
\text { 2010(Optale } \\
\text { et al., 2010) }\end{array}$ & Yes & Yes & $\begin{array}{l}\text { No, drop-puts } \\
\text { not included in } \\
\text { analyses }\end{array}$ & Yes & Yes & Yes & $\begin{array}{l}\text { Estimates for treatment effects } \\
\text { included } \\
\text { MMSE }=+4.46(p=0.044) \\
\text { Verbal Story Recall }=+4(p=-.004) \\
\text { GDS }=-3(0.255)\end{array}$ & $\begin{array}{l}\text { Effect Sizes } \\
\text { were } \\
\text { MMSE }=0.74 \\
\text { VSR }=1.02 \\
\text { GDS }=1.05\end{array}$ & Yes & $\begin{array}{l}\text { No, presence } \\
\text { not } \\
\text { considered }\end{array}$ & Yes \\
\hline $\begin{array}{l}\text { Moyle et al., } \\
2017 \text { (Moyle et } \\
\text { al., 2018) }\end{array}$ & Yes & No & Not clear & No & No* & $\mathrm{No}^{*}$ & $\begin{array}{l}\text { Observes Emotion Rating Scale: } \\
\text { Participants expressed significantly } \\
\text { more pleasure } 1.4 \text { vs } 2.8 \mathrm{p}=0.008) \\
\text { And more Alertness ( } 1.2 \text { vs } 2.4 \\
\text { p }<0.001) \text { compared with before the } \\
\text { intervention } \\
\text { Person-Environment Apathy } \\
\text { Rating: } \\
\text { Authors report statistically significant } \\
\text { lower apathy ( }(\mathrm{p}=0.005) \text { following the } \\
\text { intervention }\end{array}$ & $\mathrm{N} / \mathrm{A}$ & $\begin{array}{l}\text { No, small } \\
\text { population } \\
\text { size and no } \\
\text { control. } \\
\text { Difficult to } \\
\text { replicate } \\
\text { given } \\
\text { environment }\end{array}$ & $\begin{array}{l}\text { No, although } \\
\text { this was a } \\
\text { short } \\
\text { intervention }\end{array}$ & Yes \\
\hline $\begin{array}{l}\text { White et al., } \\
2016 \text { (White } \\
\& \\
\text { Moussavi, } \\
\text { 2016) }\end{array}$ & Yes & $\mathrm{No}^{*}$ & Yes & $\mathrm{No}^{*}$ & $\mathrm{~N} / \mathrm{A}$ & $\mathrm{N} / \mathrm{A}$ & No significant treatment effect & $\begin{array}{l}\text { No significant } \\
\text { treatment effect }\end{array}$ & No & No & Yes \\
\hline
\end{tabular}




\title{
Appendix B: Characteristics of Studies
}

\author{
Maggio et al., 2018 (Maggio et al., 2018)
}

\begin{tabular}{|l|l|}
\hline Article Breakdown & Comments \\
\hline Aim & $\begin{array}{l}\text { To evaluate the effects of a VR cognitive training system in the cognitive and behavioral recovery } \\
\text { of patients with PD }\end{array}$ \\
\hline Methods & Randomised controlled pilot/feasibility Study \\
\hline Participants & $\begin{array}{l}\text { 20 patients with Parkinson's Disease. } \\
\text { Current domiciliary status unclear } \\
\text { Recruited from Neurorehabilitation Service they were attending } \\
\text { All participants completed the study }\end{array}$ \\
\hline $\begin{array}{l}\text { Baseline Characteristics of } \\
\text { Participants }\end{array}$ & $\begin{array}{l}\text { Inclusion: (1) Hoehn Yahr <3 (2) MMSE 11-26 } \\
\text { Exclusion: (1) Over age of 85 (2) Severe medical or psychological illness (3) No disabling } \\
\text { neurosensory condition }\end{array}$ \\
\hline Intervention & Semi-immersive Virtual Reality therapy \\
\hline Frequency of Intervention & Three, one hour sessions every week for 8 weeks \\
\hline Control Details & Face-to-face therapy sessions instead of VR \\
\hline Software Details & $\begin{array}{l}\text { BTS-Nirvana software. Produced by external company with the specific goal of motor } \\
\text { rehabilitation }\end{array}$ \\
\hline Hardware Requirements & $\begin{array}{l}\text { 2 marked infrared sensors, workstation touch screen, camera supports and web cam. Takes } \\
\text { place in darkened room }\end{array}$ \\
\hline $\begin{array}{l}\text { Hardware and Software } \\
\text { Release date }\end{array}$ & Not Stated and not able to ascertain from version information \\
\hline Immersion Score & 7/10 \\
\hline Level of Presence & Not discussed in article \\
\hline Theoretical Considerations & $\begin{array}{l}\text { Considered that VR provides multisensory stimulation to create a realistic environment and } \\
\text { improve motivation and the adhesion of patients to rehabilitation. As described in the scenarios, } \\
\text { each intervention also specifically tackled one cognitive domain }\end{array}$ \\
\hline Scenarios and Activity Details & Domain \\
\hline
\end{tabular}




\begin{tabular}{|c|c|c|c|}
\hline & $\begin{array}{l}\text { Executive } \\
\text { and } \\
\text { Visuospatial } \\
\text { Attention }\end{array}$ & $\begin{array}{l}\text { Fruit association game, where patients must } \\
\text { asked to associate the colours with fruits, } \\
\text { and constructs recipes based on this } \\
\text { Patient can select different objects, names } \\
\text { the object and has to name recipes that } \\
\text { require use of that object } \\
\text { Participant asked to remember stimuli seen } \\
\text { previously in virtual environment }\end{array}$ & $\begin{array}{l}\text { Patient asked to identify the a } \\
\text { target object, whilst negating } \\
\text { distractors on paper } \\
\text { Similar activity taking place in } \\
\text { paper or pencil }\end{array}$ \\
\hline Outcomes & \multicolumn{3}{|c|}{$\begin{array}{l}\text { Estimates for treatment effects included } \\
\text { MMSE }=+2.15(p=0.014) \\
\text { ACE-R }=+12.69(p=<0.0001) \\
\text { GDS }=-0.23(p=0.812)\end{array}$} \\
\hline Notes & \multicolumn{3}{|c|}{ Nil } \\
\hline \multicolumn{4}{|l|}{ Risk of Bias } \\
\hline Bias & $\begin{array}{l}\text { Authors } \\
\text { Judgement }\end{array}$ & \multicolumn{2}{|l|}{ Support for Judgement } \\
\hline $\begin{array}{l}\text { Random Sequence } \\
\text { Generation (selection bias) }\end{array}$ & Low Risk & \multicolumn{2}{|c|}{$\begin{array}{l}\text { Paper states patients were randomly selected but not clear what method of } \\
\text { randomisation used }\end{array}$} \\
\hline $\begin{array}{l}\text { Allocation concealment } \\
\text { (selection bias) }\end{array}$ & Low Risk & \multicolumn{2}{|c|}{ 'Therapists and testers blinded', unclear how } \\
\hline $\begin{array}{l}\text { Blinding of participants and } \\
\text { personnel (performance bias) }\end{array}$ & Medium Risk & \multicolumn{2}{|c|}{$\begin{array}{l}\text { It is unclear if efforts were made to conceal which method was being tested as } \\
\text { the 'intervention' and which as the 'control' }\end{array}$} \\
\hline $\begin{array}{l}\text { Blinding of outcome } \\
\text { assessment (detection bias) }\end{array}$ & Low Risk & \multicolumn{2}{|c|}{ 'Therapists and testers blinded', unclear how } \\
\hline $\begin{array}{l}\text { Incomplete outcome data } \\
\text { (attrition bias) }\end{array}$ & Low Risk & \multicolumn{2}{|l|}{ Every participant completed the trial } \\
\hline For-profit bias & Low Risk & \multicolumn{2}{|c|}{ No conflicts of interest declared } \\
\hline Other Bias & Medium Risk & \multicolumn{2}{|c|}{$\begin{array}{l}\text { Authors did not report how many volunteers were excluded as they did not meet } \\
\text { study criteria. This would have been helpful in determining generalisability }\end{array}$} \\
\hline
\end{tabular}


Manera et al., 2016(Manera et al., 2016)

\begin{tabular}{|c|c|}
\hline Article Breakdown & Comments \\
\hline Aim & To train selective and sustained attention in Dementia and $\mathrm{MCl}$ \\
\hline Methods & Non-controlled feasibility study \\
\hline Participants & $\begin{array}{l}28 \text { participants with } \mathrm{MCl} \\
29 \text { participants with Dementia } \\
\text { Current domiciliary status unclear } \\
\text { Recruited from Research memory service they were attending } \\
\text { All participants completed the study }\end{array}$ \\
\hline $\begin{array}{l}\text { Baseline Characteristics of } \\
\text { Participants }\end{array}$ & $\begin{array}{l}\text { Inclusion: (1) MMSE 16-28 (baseline apathy also measured) } \\
\text { Exclusion: (1) Aged younger than } 60 \text { years old (2) Psychiatric disorders or major perceptual } \\
\text { impairments (3) Suffered from migraine or epilepsy (4) Motion-sickness sensitivity (5) Unable to } \\
\text { provide written consent due to severe cognitive impairment }\end{array}$ \\
\hline Intervention & Semi-immersive VR therapy \\
\hline Frequency of Intervention & $\begin{array}{l}\text { One five minute session with VR condition, followed by one five minute session with paper } \\
\text { condition in a randomised order }\end{array}$ \\
\hline Control Details & Paper condition \\
\hline Software Details & Not stated \\
\hline Hardware Requirements & $\begin{array}{l}\text { Barco OvervView OLSF-721 full HD 3D stereoscopic LED video wall. } \\
\text { 3D LCD shutter glasses } \\
\text { Wireless mouse tracker }\end{array}$ \\
\hline $\begin{array}{l}\text { Hardware and Software } \\
\text { Release Dates }\end{array}$ & Not stated \\
\hline Immersion Score & $5 / 10$ \\
\hline Level of Presence & Not stated \\
\hline Theoretical Considerations & $\begin{array}{l}\text { Considers that VR creates a more realistic environment, ability for faster feedback and a greater } \\
\text { degree of personalisation than paper tasks. VR task design was based on the principles of the } \\
\text { classical cancellation task, employed for instance in the Attention Process Training-an } \\
\text { intervention designed to rehabilitate attentional problems in people with brain injuries }\end{array}$ \\
\hline
\end{tabular}




\begin{tabular}{|c|c|c|c|}
\hline $\begin{array}{l}\text { Scenarios and Activity } \\
\text { Details }\end{array}$ & $\begin{array}{l}\text { Domain } \\
\text { No domain } \\
\text { stated. }\end{array}$ & $\begin{array}{l}\text { VR activity examples } \\
\text { Easy: Differentiating individuals wearing coloured T-shirts } \\
\text { Medium: Differentiating individuals wearing patterned T-shirts } \\
\text { Hard: Differentiating individuals by both coloured and patterned T } \\
\text { shirts }\end{array}$ & $\begin{array}{l}\text { Control } \\
\text { Same } \\
\text { activities on } \\
\text { paper. }\end{array}$ \\
\hline Outcomes & \multicolumn{3}{|c|}{$\begin{array}{l}\text { For both the VR and the paper conditions, participants reported: } \\
\text { To be highly satisfied concerning the experience }(\mathrm{VR}, \mathrm{M}=8.6 / 10, \mathrm{SD}=1.7 \text {; paper: } \mathrm{M}=8.2 / 10, \mathrm{SD} \\
=2.3 \text { ) Highly interested }(\mathrm{VR}, \mathrm{M}=8.0 / 10, \mathrm{SD}=2.3 ; \text { paper: } \mathrm{M}=7.9 / 10, \mathrm{SD}=2.2) \text {. Secure in both } \\
\text { conditions (VR,M }=9.4 / 10, \mathrm{SD}=1.3 ; \text { paper: } \mathrm{M}=9.7 / 10, \mathrm{SD}=1.1) \text {. } \\
\text { Low levels of anxiety }(\mathrm{VR}, \mathrm{M}=1.7 / 10, \mathrm{SD}=2.9 ; \text { paper: } \mathrm{M}=1.7 / 10, \mathrm{SD}=3.2) \text {, Low levels of fatigue } \\
(\mathrm{VR}, \mathrm{M}=.9 / 10, \mathrm{SD}=2.0 ; \text { paper: } \mathrm{M}=.7 / 10, \mathrm{SD}=1.8) \text { in both conditions. } \\
39 \text { participants }(68.4 \%) \text { reported that they had preferred the VR condition, } 15 \text { participants }(26.3 \%) \\
\text { reported to have preferred the paper condition, and } 3 \text { participants }(5.3 \%) \text { expressed no preference } \\
\text { Participants were significantly more satisfied in the VR condition compared to the paper condition, } \\
\text { and that they felt less secure in the VR condition compared to the paper condition }\end{array}$} \\
\hline Notes & \multicolumn{3}{|c|}{ Nil } \\
\hline \multicolumn{4}{|l|}{ Risk of Bias } \\
\hline Bias & Authors Judgement & \multicolumn{2}{|l|}{ Support for Judgement } \\
\hline $\begin{array}{l}\text { Random Sequence } \\
\text { Generation (selection bias) }\end{array}$ & $\mathrm{N} / \mathrm{A}$ & \multicolumn{2}{|l|}{ Not relevant to study method } \\
\hline $\begin{array}{l}\text { Allocation concealment } \\
\text { (selection bias) }\end{array}$ & $\mathrm{N} / \mathrm{A}$ & \multicolumn{2}{|l|}{ Not relevant to study method } \\
\hline $\begin{array}{l}\text { Blinding of participants and } \\
\text { personnel (performance } \\
\text { bias) }\end{array}$ & High risk & \multicolumn{2}{|l|}{ No control } \\
\hline
\end{tabular}




\begin{tabular}{|l|l|l|}
\hline $\begin{array}{l}\text { Blinding of outcome } \\
\text { assessment (detection } \\
\text { bias) }\end{array}$ & High risk & No control \\
\hline $\begin{array}{l}\text { Incomplete outcome data } \\
\text { (attrition bias) }\end{array}$ & Low risk & All included participants completed the study \\
\hline For-profit bias & Low Risk & $\begin{array}{l}\text { Statement declares no conflict of interest, however one author does } \\
\text { work for Disney with specific interest in VR and VR in crowds }\end{array}$ \\
\hline Other Bias & N/A & N/A \\
\hline
\end{tabular}


Optale et al., 2010(Optale et al., 2010)

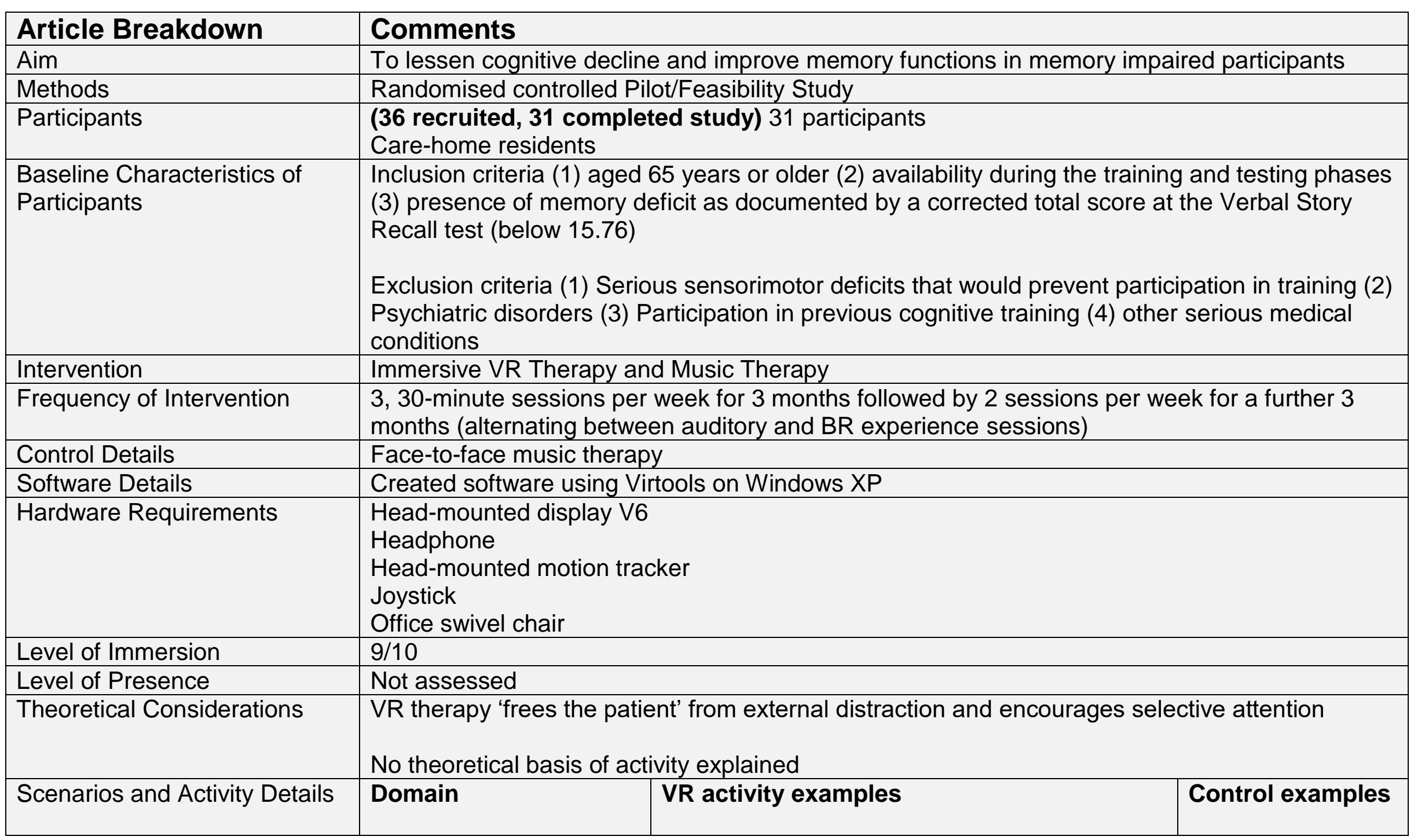




\begin{tabular}{|c|c|c|c|}
\hline & & $\begin{array}{l}\text { Auditory Experience sessions. Participants } \\
\text { listened to stories via headphones and musical } \\
\text { backgrounds were also played } \\
\text { VR Experience sessions, participants asked to } \\
\text { concentrate their attention on paths that lead to } \\
\text { the activation of film clips. }\end{array}$ & $\begin{array}{l}\text { Individual face-face } \\
\text { training sessions of } \\
\text { music therapy }\end{array}$ \\
\hline Outcomes & \multicolumn{3}{|c|}{$\begin{array}{l}\text { Estimates for effect sizes given VR therapy } \\
\text { MMSE }=+0.74(p=0.044) \\
\text { Verbal Story Recall }=+1.02(p=0.0001) \\
\text { GDS }=-1.05 \text { ( } p=0.025) \\
\text { Activities of daily living=functions }=-0.07\end{array}$} \\
\hline \multicolumn{4}{|c|}{ 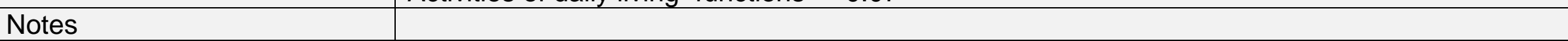 } \\
\hline \multicolumn{4}{|l|}{ Risk of Bias } \\
\hline Bias & Authors Judgement & \multicolumn{2}{|l|}{ Support for Judgement } \\
\hline $\begin{array}{l}\text { Random Sequence } \\
\text { Generation (selection bias) }\end{array}$ & Low Risk & \multicolumn{2}{|l|}{ Participants were randomised pre-trial } \\
\hline $\begin{array}{l}\text { Allocation concealment } \\
\text { (selection bias) }\end{array}$ & Low Risk & \multicolumn{2}{|l|}{ Single-blinding was conducted for assessors } \\
\hline $\begin{array}{l}\text { Blinding of participants and } \\
\text { personnel (performance bias) }\end{array}$ & Low Risk & \multicolumn{2}{|c|}{$\begin{array}{l}\text { Although unable to blind, both intervention and control were } \\
\text { substantial enough to mitigate any potential placebo effect }\end{array}$} \\
\hline $\begin{array}{l}\text { Blinding of outcome } \\
\text { assessment (detection bias) }\end{array}$ & Low risk & \multicolumn{2}{|c|}{ Single-blinding was conducted for assessors } \\
\hline $\begin{array}{l}\text { Incomplete outcome data } \\
\text { (attrition bias) }\end{array}$ & High Risk & \multicolumn{2}{|c|}{$\begin{array}{l}5 \text { participants who left the study were not included in statistical } \\
\text { analysis }\end{array}$} \\
\hline For-profit bias & Low Risk & \multicolumn{2}{|c|}{ No conflicts declared, funded by care home } \\
\hline Other Bias & None & & \\
\hline
\end{tabular}


Moyle et al., 2017 (Moyle et al., 2018)

\begin{tabular}{|c|c|c|c|}
\hline Article Breakdown & \multicolumn{3}{|c|}{ Comments } \\
\hline Aim & \multicolumn{3}{|c|}{ To improve quality of life for the person living with dementia } \\
\hline Methods & \multicolumn{3}{|c|}{$\begin{array}{l}\text { Non-controlled pilot /feasibility study with qualitative component exploring experiences of } \\
\text { staff, people with dementia and their families }\end{array}$} \\
\hline Participants & \multicolumn{3}{|c|}{$\begin{array}{l}10 \text { participants with dementia } \\
10 \text { family members } \\
9 \text { care staff } \\
\text { All participants completed the study }\end{array}$} \\
\hline $\begin{array}{l}\text { Baseline Characteristics of } \\
\text { Participants }\end{array}$ & \multicolumn{3}{|c|}{$\begin{array}{l}\text { Inclusion: (1) Documented diagnosis of dementia (2) aged over } 60 \text { years of age. No exclusion } \\
\text { stated }\end{array}$} \\
\hline Interventions & \multicolumn{3}{|c|}{ Semi-immersive VR therapy } \\
\hline Frequency of Intervention & \multicolumn{3}{|c|}{ One 15 minute session } \\
\hline Control Details & \multicolumn{3}{|c|}{ No control present } \\
\hline Software Details & \multicolumn{3}{|l|}{ Not stated } \\
\hline Hardware Requirements & \multicolumn{3}{|c|}{$\begin{array}{l}\text { Large interactive screen } \\
\text { Xbox Kinect motion sensors } \\
\text { Audio feedback }\end{array}$} \\
\hline Level of Immersion & \multicolumn{3}{|c|}{$7 / 10$} \\
\hline Level of Presence & \multicolumn{3}{|l|}{ Not assessed } \\
\hline Theoretical Considerations & \multicolumn{3}{|l|}{ Unclear } \\
\hline Scenarios and Activity Details & $\begin{array}{l}\text { Domain } \\
\text { No domain stated }\end{array}$ & $\begin{array}{l}\text { VR activity examples } \\
\text { Navigating a virtual reality forest }\end{array}$ & $\begin{array}{l}\text { Control examples } \\
\text { No control }\end{array}$ \\
\hline Outcomes & \multicolumn{3}{|c|}{$\begin{array}{l}\text { Observes Emotion Rating Scale: } \\
\text { Participants expressed significantly more pleasure } 1.4 \text { vs } 2.8 \mathrm{p}=0.008 \text { ) } \\
\text { And more Alertness ( } 1.2 \text { vs } 2.4 \mathrm{p}<0.001 \text { ) compared with a baseline group of dementia } \\
\text { patients (baseline data collected in } 1999 \text { ) } \\
\text { Person-Environment Apathy Rating: }\end{array}$} \\
\hline
\end{tabular}




\begin{tabular}{|c|c|c|}
\hline & \multicolumn{2}{|c|}{$\begin{array}{l}\text { Authors report statistically significant lower apathy }(\mathrm{p}=0.005) \text { following the intervention } \\
\text { Type of Engagement: } \\
\text { No significant differences in the type of engagement noted (distribution of time spent in 'self- } \\
\text { engagement', 'facilitated engagement' and 'no engagement' }\end{array}$} \\
\hline Notes & \multicolumn{2}{|c|}{$\begin{array}{l}\text { The study took place in two separate care homes, the authors note that results were very } \\
\text { different by facility. Once facility offered a quiet dark room with dimmed lighting with little } \\
\text { background noise to conduct the intervention, whereas the other facility offered a room near } \\
\text { a social room with a budgerigar present. The VR intervention appeared to allow for a varied } \\
\text { level of involvement of a facilitator which may effect external validity } \\
\text { Also note that there is significant qualitative assessment of families and staff - this has not } \\
\text { been included for analyses as it is not within the scope of this review }\end{array}$} \\
\hline \multicolumn{3}{|c|}{ 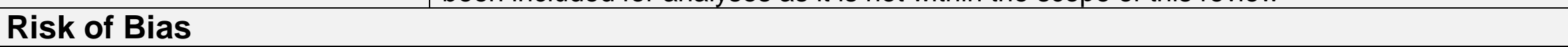 } \\
\hline Bias & Authors Judgement & Support for Judgement \\
\hline $\begin{array}{l}\text { Random Sequence Generation } \\
\text { (selection bias) }\end{array}$ & $\mathrm{N} / \mathrm{A}$ & Not relevant to study method \\
\hline $\begin{array}{l}\text { Allocation concealment } \\
\text { (selection bias) }\end{array}$ & $\mathrm{N} / \mathrm{A}$ & Not relevant to study method \\
\hline $\begin{array}{l}\text { Blinding of participants and } \\
\text { personnel (performance bias) }\end{array}$ & High risk & No control \\
\hline $\begin{array}{l}\text { Blinding of outcome assessment } \\
\text { (detection bias) }\end{array}$ & High risk & No control \\
\hline $\begin{array}{l}\text { Incomplete outcome data } \\
\text { (attrition bias) }\end{array}$ & Low risk & All included participants completed the study \\
\hline For-profit bias & Low Risk & $\begin{array}{l}\text { Statement declares no conflict of interest, research was } \\
\text { funded by Alzheimer's Australia Vic }\end{array}$ \\
\hline Other Bias & $\mathrm{N} / \mathrm{A}$ & $\mathrm{N} / \mathrm{A}$ \\
\hline
\end{tabular}


White et al., 2016(White \& Moussavi, 2016)

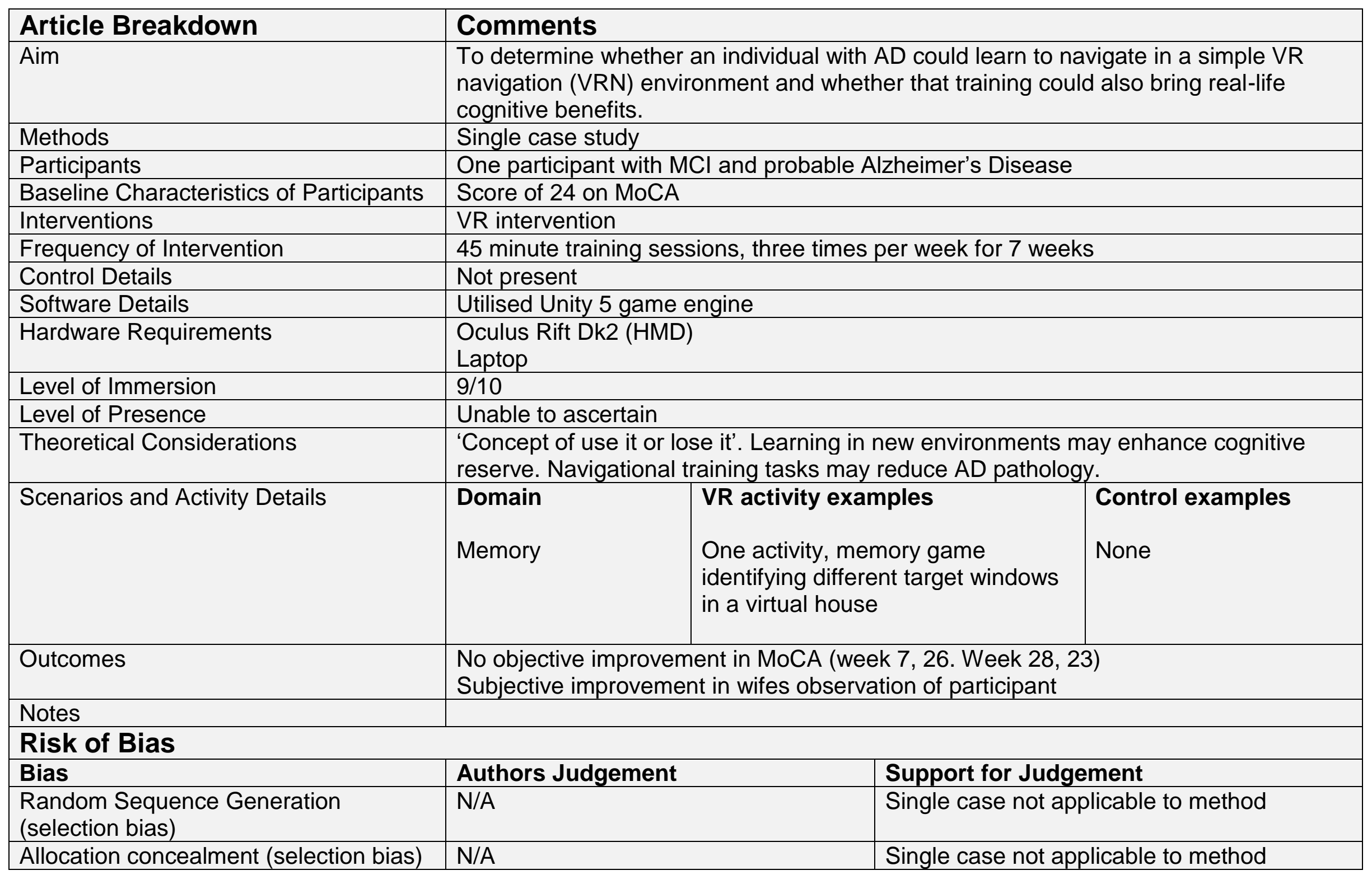




\begin{tabular}{|l|l|l|}
\hline $\begin{array}{l}\text { Blinding of participants and personnel } \\
\text { (performance bias) }\end{array}$ & High risk & Single case \\
\hline $\begin{array}{l}\text { Blinding of outcome assessment } \\
\text { (detection bias) }\end{array}$ & High risk & Single case \\
\hline Incomplete outcome data (attrition bias) & Low Risk & Single patient who completed course \\
\hline For-profit bias & No conflicts of interest & \\
\hline Other Bias & N/A & \\
\hline
\end{tabular}

